\title{
NOTE
}

\section{Growth patterns and demography of pioneer Caribbean seagrasses Halodule wrightii and Syringodium filiforme}

\author{
Margarita E. Gallegos ${ }^{1}$, Martín Merino ${ }^{2}$, Aimé Rodriguez ${ }^{1}$, Núria Marbàa $^{3}$, Carlos M. Duarte ${ }^{3, *}$ \\ ${ }^{1}$ Departamento de Hidrobiología, Universidad Autónoma Metropolitana - Iztapalapa, Michoacán y Purísima, Col. Vicentina, AP 55-535, \\ 09340 México, D.F., Mexico \\ ${ }^{2}$ Instituto de Ciencias del Mar y Limnología, Universidad Nacional Autónoma de México, AP 70-305, 04510 México, D.F., Mexico \\ ${ }^{3}$ Centro de Estudios Avanzados de Blanes, CSIC, Camino de Santa Bárbara sn, E-17300 Blanes, Girona, Spain
}

\begin{abstract}
The shoot demography and rhizome growth of Syringodium filiforme Kütz. and Halodule wrightii Aschers. were studied, based on plant dating techniques, to account for their role as pioneer in the succession sequence of Caribbean seagrasses. Results demonstrated that these species are able to develop dense meadows, supporting biomasses in excess of $500 \mathrm{~g} \mathrm{DW} \mathrm{m}^{-2}$ They produced more than $2000 \mathrm{~g} \mathrm{DW} \mathrm{m}^{-2} \mathrm{yr}^{-1}$ due to their high leaf (5.0 to $\left.8.5 \mathrm{yr}^{-1}\right)$ and rhizome $\left(2.0\right.$ to $\left.3.3 \mathrm{yr}^{-1}\right)$ turnover. Rhizome growth and branching rates were very high, allowing these seagrasses to rapidly occupy the space they colonise. The rapid rhizome turnover involved, however, a high shoot mortality rate and low life expectancy (average shoot life expectancy 100 to $180 \mathrm{~d}$ ). This implies that, while these pioneer species are able to rapidly occupy the space they colonise, their established shoots cannot occupy that space for as long as the more longlived species Thalassia testudinum. We suggest, therefore, that the role of seagrass species as pioneer or climax species is independent of their capacity to support dense, productive populations, and is closely related to shoot longevity and rhizome turnover.
\end{abstract}

KEY WORDS: Rhizome growth - Shoot age - Biomass Production

The seagrasses Syringodium filiforme Kütz. and Halodule wrightii Aschers, occupy an important role as pioneer species in the Caribbean Sea (den Hartog 1971, Patriquin 1975). They colonise denuded sediments following perturbations, preceding the climax community of Thalassia testudinum Banks ex König in the successional sequence of Caribbean seagrasses (den Hartog 1971, Patriquin 1975, Williams 1987, 1990). S. filiforme and $H$. wrightii also develop mono-

- Addressee for correspondence specific meadows in the area (Gilbert \& Clark 1981, Iverson \& Bittaker 1986, Van Tussenbroek 1994), so that, in addition to their role as pioneer species, they may also be important primary producers (Zieman et al. 1989, Short et al. 1993). Most studies on these species have focused on leaf biomass and production (Virnstein 1982, Fry 1983, Barber \& Behrens 1985, Iverson \& Bittaker 1986, Eleuterius 1987, Williams 1987. Fry \& Virnstein 1988, Zieman et al. 1989, Van Tussenbroek 1994), but reports of their rhizome growth and demography are as yet few (Eleuterius 1987, Zieman et al. 1989, Duarte 1991). Knowledge of their rhizome growth rates and demographic dynamics would, however, help to interpret the dynamics and maintenance of the meadows these species develop (Duarte \& SandJensen 1990a, b).

On the basis of data obtained using plant dating techniques (Patriquin 1973, Gallegos et al. 1993, Duarte et al. 1994, Marbà et al. 1994), we describe the biomass, and rhizome and shoot dynamics of monospecific Syringodium filiforme and Halodule wrightil meadows in the Mexican Caribbean.

Methods. We studied shallow (1.0 to $1.5 \mathrm{~m})$ monospecific meadows of Syringodium filiforme and Halodule wrightii on the reef lagoon near the town of Puerto Morelos $\left(21^{\circ} \mathrm{N}, 87^{\circ} \mathrm{W}\right.$, Yucatán Peninsula, Mexico; Marbà et al. 1994), using the approach described by Gallegos et al. (1993). In August 1991, the time of maximum seagrass biomass in the area (Van Tussenbroek 1994), we randomly collected 6 and 3 cores $(20.5 \mathrm{~cm}$ internal diameter) from the $S$. filiforme and $H$. wrightii meadows, respectively. The cores were pushed $40 \mathrm{~cm}$ into the sediment to collect the shoots down to their insertion in the rhizomes, which was needed to esti- 
mate shoot age (cf. Gallegos et al. 1993). Sediment (coarse carbonate sand) was then carefully washed off the samples, all the living shoots and the standing leaves they supported were counted, and the presence of flowers or fruits recorded. We also noted the number of branches in the horizontal rhizomes as well as the number and length of rhizome internodes between consecutive shoots and those in the entire sample, to estimate rhizome growth (cf. Gallegos et al. 1993).

The age of living (i.e. bearing green leaves) and dead (i.e. devoid of green leaves) shoots was estimated as the sum of the number of leaf scars and standing leaves (Patriquin 1973, Cox \& Tomlinson 1988, Gallegos et al. 1993). Dead shoots were dated only if they ended in a rounded tip, indicating that the shoot was not broken (Gallegos et al, 1993). The age units obtained were plastochrone intervals (PIs), which represent the average time interval between the initiation of 2 successive leaves on a shoot (Erickson \& Michelini 1957, Brouns 1985). Using a dissecting microscope, we examined the time course of vertical internodal length of the oldest shoots sampled, to identify annual cycles in the length of vertical internodes (cf. Duarte et al. 1994, Marbá et al. 1994). The inverse of the number of internodes in a cycle (number of leaves $\mathrm{yr}^{-1}$ ) corresponds to the annual average PI (cf. Duarte et al. 1994, Marbá et al. 1994) which was used to convert PIs into absolute time units.

The data set obtained in August 1991 was complemented with information on flowering frequency, maximal shoot age, and additional sequences of internodal length for old shoots. These were obtained during 2 more visits in the spring of 1992 and 1993 (sample sizes about 2000 and 4000 shoots for Syringodium filiforme and Halodule wrightii, respectively).

The PI of horizontal rhizomes was calculated by regressing the number of rhizome internodes between shoots along the rhizome against their age difference (Patriquin 1973, Gallegos et al. 1993). The rate of vertical growth of Syringodium filiforme and Halodule wrightii shoots was also calculated by regressing shoot length against age (Gallegos et al 1993). Shoot age structure was described using data on living and dead shoots (Gallegos et al. 1993, Duarte et al. 1994). The average age of living shoots represents the overall age of the shoot population, but it does overestimate their life expectancy, which is best represented by the age at death (Gallegos et al, 1993, Duarte et al. 1994). Shoot mortality $(K$, in natural logarithm units time $^{-1}$; of $\cdot$ Duarte \& Sand-Jensen 1990b) was calculated from the age distribution of dead shoots (Gallegos et al. 1993, Duarte et al.
1994) by fitting the equation

$$
N_{t}=N_{0} \mathrm{e}^{-k t}
$$

which describes the exponential decline in shoot number $(N)$ in increasingly older age classes with time $(t)$ from the onset on mortality $(t=0)$. Shoot recruitment rates were then calculated as the natural logarithm of the inverse of the fraction of the shoot population older than 1 yr (Duarte \& Sand-Jensen 1990b).

Results. Halodule wrightii and Syringodium filiforme developed lush monospecific stands in the reef lagoon, reaching a high shoot density and high biomass of shoots and rhizomes (Table 1). Rhizome internodes of $S$. filiforme were thicker and longer than those of $H$. wrightii $(30.6 \pm 0.25$ and $20.2 \pm 1.0 \mathrm{~mm}$ internode $e^{-1}$, respectively), and the 2 species formed a dense network of $228.5 \mathrm{~m}$ and $216.8 \mathrm{~m}$ of rhizome $\mathrm{m}^{-2}$, respectively. Shoot density closely resembled rhizome internode density (Table 1), because both species produce 1 short shoot at each rhizome internode. The number of internodes between connected shoots and their age difference were closely correlated ( $p<0.0001)$. The slope of the regression equations describing these relationships indicated that $H$. wrightii and $S$. filiforme produce $1.81 \pm 0.17$ and 2.81 \pm 0.27 internodes $\mathrm{PI}^{-1}$, respectively. Shoot vertical growth was calculated from regression analysis between shoot length and shoot age to be $0.56 \pm 0.13$ and $0.12 \pm 0.01 \mathrm{~cm} \mathrm{PI}^{-1}$ for $S$. filiforme and $H$. wrightii, respectively (Fig, 1). The distinct seasonal pattern in the sequence of vertical internodal length (Fig. 2) allowed calculation of the average number of vertical internodes (= number of leaves) produced per shoot per year, and the average PI for the 2 species (Table 1), which were used to calculate annual rates of rhizome elongation from rates per PI (Table 1). Rhizomes branched in $3.2 \%$ and $9.3 \%$ of the rhizome

Table 1. Syringodium filiforme and Halodule wrightii. Average ( $\pm \mathrm{SE}$ ) shoot and rhizome biomass, density, production, and shoot recruitment and mortality rates for the populations studied

\begin{tabular}{|c|c|c|}
\hline Variable & S. filiforme & H. wrightii \\
\hline Shoot biomass (g DW $\mathrm{m}^{-2}$ ) & $446.9 \pm 48.4$ & $519 \pm 86$ \\
\hline Shoot density (shoots $\mathrm{m}^{-2}$ ) & $7139 \pm 1366$ & $14872 \pm 2444$ \\
\hline Rhizome biomass (g DW m-2) & 233 & 97 \\
\hline Rhizome density (internodes $\mathrm{m}^{-2}$ ) & 7468 & 10732 \\
\hline Leaf plastochrone interval (d) & 60.8 & 16.5 \\
\hline Leaves shoot ${ }^{-1} \mathrm{yr}^{-1}$ & 6 & 22.1 \\
\hline Rhizome elongation ( $\mathrm{cm} \mathrm{yr}^{-1} \mathrm{apex}^{-1}$ ) & 51.6 & 80.9 \\
\hline Vertical growth $\left(\mathrm{cm} \mathrm{yr}^{-1}\right.$ shoot $\left.^{-1}\right)$ & 3.36 & 2.65 \\
\hline Shoot recruitment (ln units $\mathrm{yr}^{-1}$ ) & 0.77 & 4.18 \\
\hline Shoot mortality rate (ln units $\mathrm{yr}^{-1}$ ) & $2.04 \pm 0.39$ & $3.54 \pm 0.37$ \\
\hline Leaf production (g DW m $\mathrm{m}^{-2} \mathrm{yr}^{-1}$ ) & 2234 & 4619 \\
\hline Rhizome production ( $\mathrm{g} \mathrm{DW} \mathrm{m} \mathrm{m}^{-2} \mathrm{yr}^{-1}$ ) & 466 & 320 \\
\hline
\end{tabular}



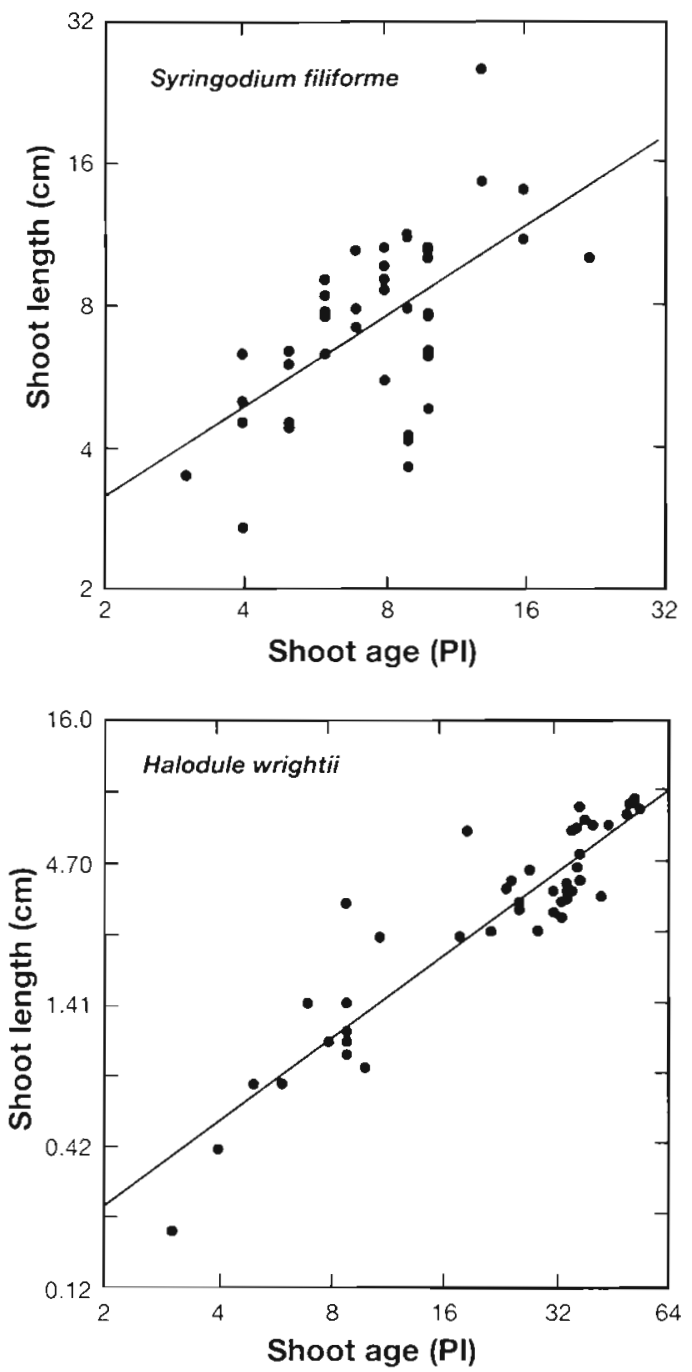

Fig. 1. Syringodium filiforme and Halodule wrightii. Relationship between the length of vertical rhizomes and the age of shoots

internodes examined for $S$. filiforme and $H$. wrightii, respectively.

The average age of Syringodium filiforme shoots was ca 1 yr $(6.7 \pm 0.1$ PIs $)$, and most of the shoots had been produced within the current year (i.e. age $<7$ PIs; Fig. 3), indicative of a high shoot recruitment rate (Table 1). The age distribution of dead shoots (Fig. 3) showed a clear exponential decline in survival with increasing age that allowed calculation of mortality rates (Table 1). The average life expectancy of $S$. filiforme shoots was found to be about half a year $(3 \pm$ 0.16 PIs) and the oldest $S$. filiforme shoot found was about 7 yr (46 PIs, $n>2000$ ). Almost all of the living Halodule wrightii shoots had been produced within a year (Fig. 4), indicating very high shoot recruitment rates (Table 1 ). High rates are needed to compensate
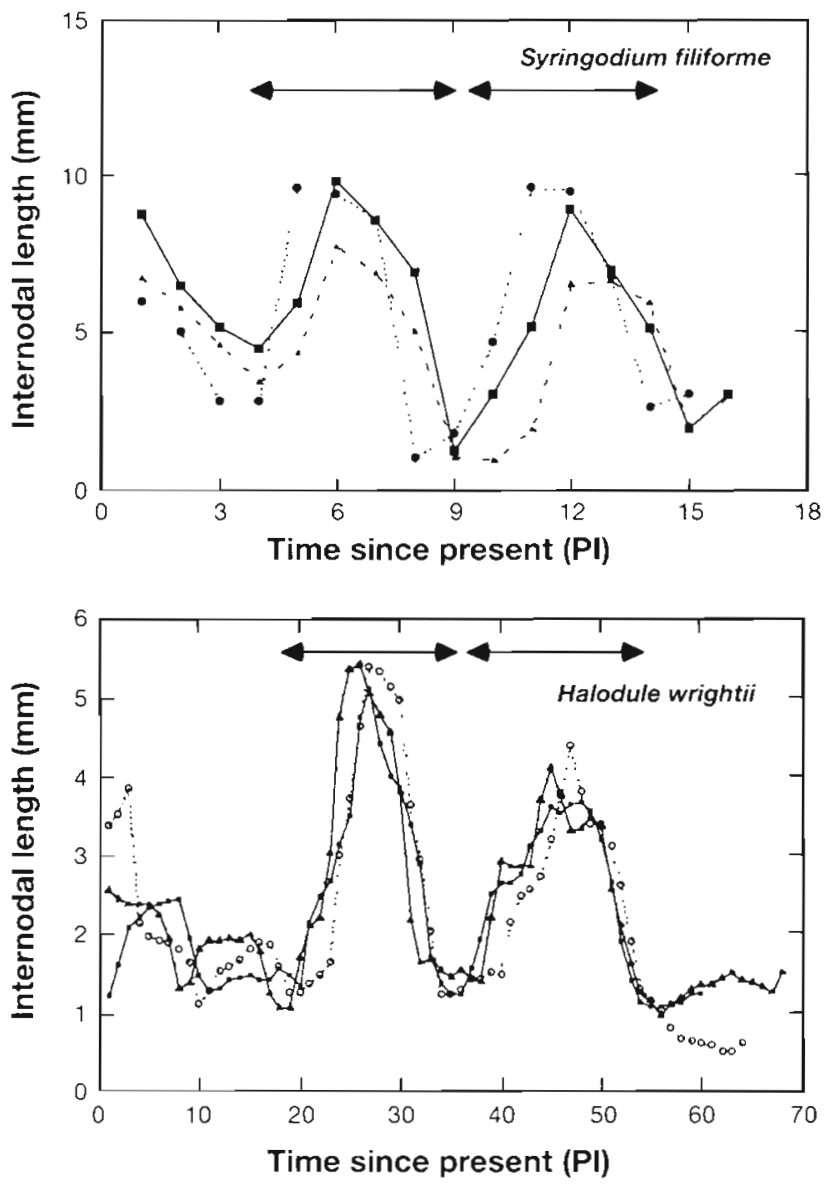

Fig. 2. Syringodium filiforme and Halodule wrightii. Sequence of internodal length recorded for the oldest shoots sampled. Arrows indicate annual cycles

for their high mortality rate (Table 1), as reflected by the rapid exponential decline in shoot abundance with increasing shoot age (Fig. 4). The life expectancy of $H$. wrightii shoots is, therefore, only about 3 mo or $6.9 \pm$ $0.4 \mathrm{PIs}$, and the longest-lived shoot found was only $3 \mathrm{yr}$ (70 PIs, $n>4000$ ).

The average shoot life expectancies estimated (182 and $110 \mathrm{~d}$ for Syringodium filiforme and Halodule wrightii, respectively) will, in a stable population, correspond to their shoot turnover time (Gallegos et al. 1993), which are, therefore, about 2.0 and $3.3 \mathrm{yr}^{-1}$. These estimates should also be close to the average rhizome turnover rates (Gallegos et al. 1993), because shoot turnover is maintained by a parallel rhizome turnover (i.e. 1 internode is formed for each shoot producedj. An estimate of the average number of leaves that a shoot produces per year, together with the average number of standing leaves per shoot $(2.6 \pm 0.1$ and $1.2 \pm 0.03$ leaves shoot ${ }^{-1}$ ), allows the leaf turnover to be calculated as 8.5 and $5.0 \mathrm{yr}^{-1}$ for $H$. wrightii and $S$. filiforme, respectively. Hence, leaf turnover is about twice 

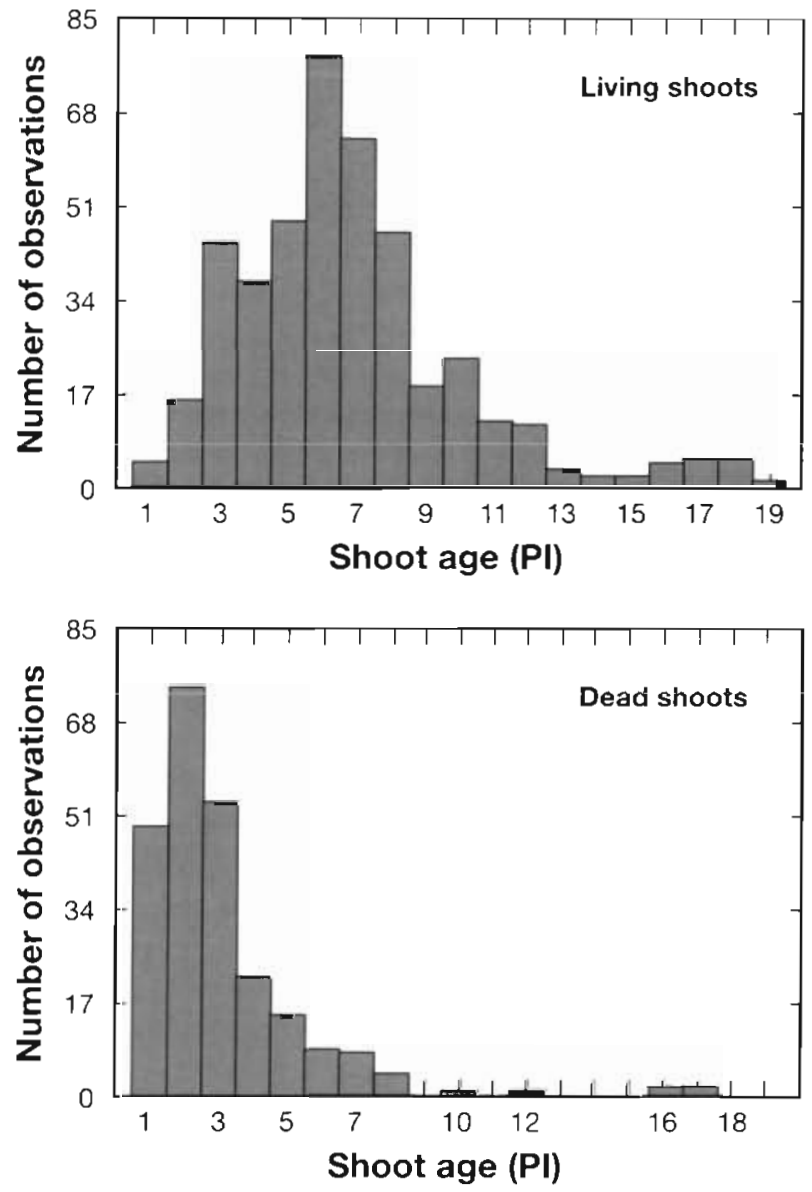

Fig. 3. Syringodium filiforme. Age distribution of living and dead shoots

as fast as rhizome turnover. The calculated turnover rates combined with the biomass of leaves and rhizomes (Table 1), which show little seasonal variation in this area (Van Tussenbroek 1994), reveal the production of the 2 species to be nearly 3 and $5 \mathrm{~kg} \mathrm{DW} \mathrm{m}^{-2}$ $\mathrm{yr}^{-1}$, respectively (Table 1 ).

Syringodium filiforme and Halodule wrightii flowered in spring, and $6.4 \%$ and $10.5 \%$, respectively, of their shoots had flowered in spring 1993, representing about 300 and 1500 flowering shoots $\mathrm{m}^{-2}$, respectively. Flowering shoots had an average age of $8.4 \pm 0.8$ PI for $S$. filiforme and $29.3 \pm 2.7 \mathrm{PI}$ for $H$. wrightii, which indicates flowering to be more frequent for shoots older than 1 yr. In August 1991, 366 fruiting $H$. wrightii shoots $\mathrm{m}^{-2}$ were found, with each fruit-bearing shoot having 2 fruits, which indicates that only about $20 \%$ of the flowering shoots set fruit.

Discussion. The results obtained showed that the 2 species are able to develop lush, highly productive meadows in the Mexican Caribbean (Table 1). The shoot density and biomass were greater than values
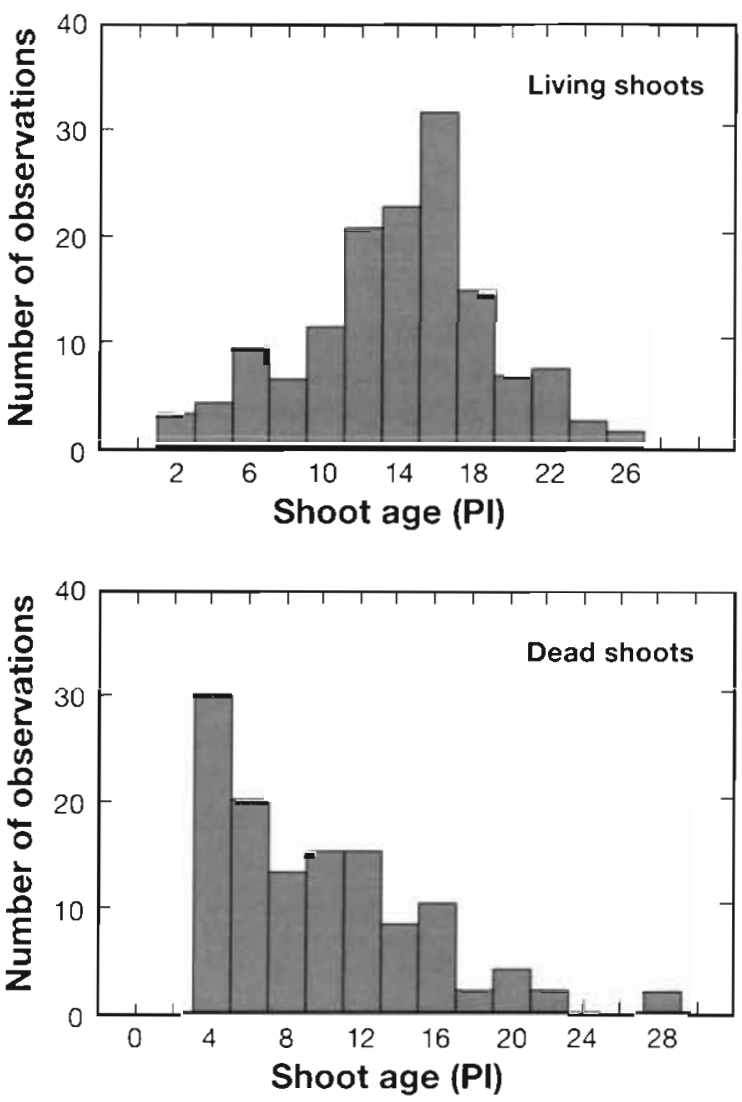

Fig. 4. Halodule wrightii. Age distribution of living and dead shoots

reported to date for the Gulf of Mexico (e.g. Eleuterius 1987) and the Atlantic Ocean (Short et al. 1993), although $S$. filiforme has been observed to produce even larger biomasses, close to $1 \mathrm{~kg} \mathrm{DW} \mathrm{m}^{-2}$, in the Mexican Caribbean (Van Tussenbroek 1994). The biomass and production of $S$. filiforme and $H$. wrightii (Table 1) were each comparable to that of $T$. testudinum, the climax species, in this area (Gallegos et al. 1993).

The 2 populations of Syringodium filiforme and Halodule wrightii studied had higher horizontal elongation rates (Table 1) than those reported in the northern Gulf of Mexico (Eleuterius 1987), although S. filiforme rhizomes grew at rates similar to that reported for the Indian River Lagoon (Florida, USA; Short et al. 1993). Rhizome growth rates for the species investigated were 2 - to 4 -fold greater than those of Thalassia testudinum in the Caribbean $\left(22.3 \mathrm{~cm} \mathrm{yr}^{-1}\right.$; Gallegos et al. 1993). In addition to their higher growth rate, $S$. filiforme and $H$. wrightii also branched at every 94 and $21.8 \mathrm{~cm}$, respectively, whereas $T$. testudinum produces 1 branch for every $6300 \mathrm{~cm}$ of horizontal rhizome (Gallegos et al. unpubl.). Hence, $S$. filiforme and $H$. wrightii are able to colonise and occupy space much faster than 
T. testudinum. Moreover, the density of flowering $H$ wrightii and $S$. filiforme shoots is about 10 - to 50 -fold greater than that of $T$. testudinum (Gallegos et al. 1992. 1993), further contributing to the ability of these species to colonise unvegetated sediments faster than the climax species.

The high growth rate and associated high mortality rate of Syringodium filiforme and Halodule wrightii (Table 1) imply that these pioneer species must have high nutrient requirements (Fourqurean et al. 1992 Short et al. 1993, Duarte 1994). The rapid loss of $S$. filiforme and $H$. wrightii material, which represents the bulk of the abundant seagrass material washed onto the shoreline, associated with the short life-span of their leaves and shoots, must also reduce their capacity for nutrient storage and internal recycling. In contrast, Thalassia testudinum grows slower and lives much longer (Gallegos et al. 1993), and should, accordingly, have lower nutrient requirements (Fourqurean et al. 1992, Duarte 1994), and be better able to store and recycle nutrients (Patriquin 1972).

These observations help explain why Thalassia testudinum is the climax species in the Caribbean, and why the dense meadows developed by Srringodium filiforme and Halodule wrightii are eventually replaced by meadows of the longer-lived climax species in oligotrophic Caribbean ecosystems. Our results also demonstrate important differences in the reproductive output and rhizome growth of the 2 pioneer species. The areal density of $H$. wrightii flowering shoots was 5fold greater than that of $S$. filiforme, which also had a slower rhizome growth and turnover. Hence, S. filiforme presents an intermediate reproductive effort, rhizome turnover, and shoot longevity between $H$. wrightii and $T$. testudinum, and indeed occupies an intermediate position in the Caribbean seagrass successional sequence (den Hartog 1971, Williams 1990).

\section{LITERATURE CITED}

Barber, B. J., Behrens, P. J. (1985). Effects of elevated temperature on seasonal in situ leaf productivity of Thalassia testudinum Banks ex König and Syringodium filiforme Kützing. Aquat. Bot. 22: 61-69

Birch, W. R., Birch, M. (1984). Succession and pattern of tropical intertidal seagrasses in Cockle Bay, Queensland, Australia: a decade of observations. Aquat. Bot. 19: 343-367

Brouns, J. J. W. M. (1985). The plastochrone interval method for the study of the productivity of seagrasses; possibilities and limitations. Aquat. Bot. 21.71-88

Cox, P. A., Tomlinson, P. B. (1988). Pollination ecology of seagrass, Thalassia testudinum (Hydrocharitaceae), in St. Croix. Am. J. Bot. 75: 958-965

den Hartog, C. (1971). The dynamic aspect in the ecology of sea-grass communities. Thalassia jugosl. 7: 101-112

Duarte, C. M. (1991). Allometric scaling of seagrass form and productivity. Mar. Ecol. Prog. Ser. 77: 289-300
Duarte, C. M. (1994). Submerged aquatic vegetation in relation to different nutrient regimes. Ophelia (in press)

Duarte, C. M., Marbà, N., Agawin, N., Cebrián, J., Enríquez, S., Fortes, M. D., Gallegos, M. E., Merino, M., Olesen, B., Sand-Jensen, K., Uri, J., Vermaat, J (1994). Reconstruction of seagrass dynamics: age determinations and associated tools for the seagrass ecologist. Mar Ecol. Prog. Ser (in press)

Duarte, C. M., Sand-Jensen, K. (1990a). Seagrass colonisation: patch formation and patch growth in Cymodocea nodosa. Mar. Ecol. Prog. Ser. 65: 193-200

Duarte, C. M., Sand-Jensen, K. (1990b). Seagrass colonisation: biomass development and shoot demography in Cymodocea nodosa. Mar. Ecol. Prog. Ser. 67: 97-103

Eleuterius, L. N. (1987). Seagrass ecology along the coasts of Alabama, Louisiana, and Mississippi. In: Durako, M. J.. Phillips, R. C., Lewis, R. R. IIr (eds.) Proc. Symp. Subtropical-Tropical Seagrasses Southeastern United States. Fla mar. Res. Publ. 42: 11-20

Erickson, R. O., Michelini, F. J. (1957). The plastochrone index. Am. J. Bot. 44: 297-305

Fourqurean, J. W., Zieman, J. C., Powell, G. V. N. (1992). Relationships between porewater nutrient and seagrasses in a subtropical carbonate environment. Mar. Biol. 114 $57-65$

Fry, B. (1983). Leaf growth in the seagrass Syringodium filiforme Kütz. Aquat. Bot. 16: 361-368

Fry, B., Virnstein, R. W. (1988). Leaf production and export of the seagrass Syringodium filiforme Kütz. in Indian River lagoon, Florida. Aquat. Bot. 30: 261-266

Gallegos, M. E., Merino, M., Marbà, N., Duarte, C. M. (1992). Flowering of Thalassia testudinum in the Mexican Caribbean: age-dependence and interannual variability. Aquat. Bot. 43: 249-255

Gallegos, M. E., Merino, M., Marbà, N., Duarte, C. M. (1993). Biomass and dynamics of Thalassia testudinum in the Mexican Caribbean: elucidating rhizome growth. Mar. Ecol. Prog. Ser. 95: 185-192

Gilbert, S., Clark, K. B. (1981). Seasonal variation in standing crop of the seagrass Syringodium filiforme and associated macrophytes in the northern Indian River, Florida. Estuaries 4: 223-225

Iverson, R. L., Bittaker, H. F. (1986). Seagrass distribution and abundance in eastern Gulf of Mexico coastal waters Estuar. coast. Shelf Sci. 22: 577-602

Marbà, N., Gallegos, M. E., Merino, M., Duarte, C. M. (1994). Vertical growth of Thalassia testudinum: seasonal and interannual variability. Aquat. Bot. 47: 1-11

Patriquin, D. G. (1972). The origin of nitrogen and phosphorus for growth of the marine angiosperm Thalassia testudinum. Mar. Biol. 15:35-46

Patriquin, D. G. (1973). Estimation of growth rate, production and age of the marine angiosperm Thalassia testudinum König. Carib. J. Sci. 13: 111-123

Patriquin, D. G. (1975). 'Migration' of blowouts in seagrass beds at Barbados and Carriacau, West Indies, and its ecological and geological implications. Aquat. Bot. 1: 163-189

Short, F. T., Montgomery, J., Zimmermann, C. F., Short, C. A. (1993). Production and nutrient dynamics of a Syringodium filiforme Kütz. seagrass bed in Indian River Lagoon, Florida. Estuaries 16: 323-334

Van Tussenbroek, B. (1994). Spatial and seasonal variability in biomass and leaf morphology of the manatee grass, Syringodium filiforme in a tropical coral reef lagoon, Mexico. Ann. Inst. Cien. del Mar y Limnol. UNAM, México (in press)

Virnstein, R. W. (1982). Leaf growth rate of the seagrass Halo- 
dule wrightii photographically measured in situ. Aquat. Bot. 12: 209-218

Williams, S. L. (1987). Competition between the seagrasses Thalassia testudinum and Syringodium filiforme in a Caribbean lagoon. Mar. Ecol. Prog. Ser. 35: 91-98

This note was presented by G. W. Thayer (Senior Editorial Advisor), Beaufort, N. Carolina, USA
Williams, S. L. (1990). Experimental studies of Caribbean seagrasses bed development. Ecol. Monogr. 60: 449-469

Zieman, J. C., Fourqurean, J. W., Iverson, R. L. (1989). Distribution, abundance, and productivity of seagrasses and macroalgae in Florida Bay. Bull. mar. Sci. 44: 292-311

Manuscript first received: September 20, 1993 Revised version accepted: January 19, 1994 